\title{
Nutrient Compostion and Functional Properties of Afzelia Africana Seed.
}

\author{
Adebayo, S.F $F^{1 *}$ And Ojo O.C ${ }^{2}$ \\ 1. Department of Food Technology, The Federal Polytechnic, Ado-Ekiti. Nigeria \\ 2. Department of Biochemistry, University of Ado-Ekiti, Ekiti State, Nigeria
}

\begin{abstract}
Afzelia africana seed were processed into flour in the laboratory and evaluated for its proximate, mineral composition and functional properties. The results of the evaluation showed that roasting increases the crude protein content from $18.75-21.90$, crude fat from $16.90-22.70$ and crude fibre from $0.13-2.00 \%$. The moisture content reduces greatly on roasting from $7.45-3.00 \%$. Roasting significantly reduces the mineral composition $(P<0.05)$ of the seed flour. The functional properties has significant effect $(P<0.05)$ on the water absorption capacity, Oil absorption capacity and emulsion capacity with values of $140.00-125.00 \mathrm{~g} / \mathrm{g}, 88.00$ $60.00 \mathrm{~g} / \mathrm{g}, 50.00-30.00 \mathrm{ml} / \mathrm{g}$ respectively. The various parameters investigated reveal the potential of Afzelia africana as a seed that could serve as a source of health benefit when used as food supplement in food formulation.
\end{abstract}

Key words: underutilized seeds, functional properties, proximate composition.

\section{Introduction.}

Protein -energy malnutrition is among the most serious problem tropical developing countries are facing. This can be attributed mainly to the ever -increasing population as well as to the enhanced dependence on a cereal-based diet; scarcity of fertile land, degradation of natural resources (Deshpande, 1992: Steiner, 1996: FAO, 2000). It has been estimated that 800 million malnourished people exist in some of the least developed countries (Myers 2002). Apart from this, high prices of available staple foods and policy constraints on food imports are also contributing factors that have been worsening the food situation in the developing countries (Weaver, 1994). In eradicating extreme poverty and hunger attention has been shifted into aggressive research into some underutilized indigenous tree plant, example of such plant is Afzelia africana .

A. africana popularly called African oak is most widely distributed species in Africa. The plant is used in local medicine for general pain relief and digestive problems. Afzelia africana like other common legumes are underutilized except as soup thickner. Therefore this study investigated the proximate composition, mineral composition and functional properties of the fresh and roasted seed flours in other to enhance its wider application in food system.

\section{Materials and Methods}

Seeds of A.africana were purchased from the central market Ado -Ekiti ,Ekiti-State .The seeds were cleaned and dehulled in the air oven at 150 oc for 20 minutes. The hulls were removed by aspiration of the seed and cleaned. The endosperm was dried milled and sieved. The seed flour were analyzed for proximate composition, mineral composition using AAS and the functional properties determined using standard analytical procedures (AOAC,1998; Oshodi and Ekperigin ,1998).

\section{Results and Discussion}

Table 1 shows the results of the proximate and mineral compositions of the roasted and fresh seed flour of A.africana. The moisture content for the fresh seed $(7.45+0.02 \%)$ were higher than 4.85 as reported for gourd seed (Ogungbenle, 2006), pumpkin seed (5.02 \%) (Aisegbu ,1987). Roasting reduces the moisture content to $3.05+0.05 \%$ which were relative for dried food sample. The Protein content increases on roasting from $18.75+0.03$ to $21.90+0.04 \%$. When compared with the protein of other leguminous seed fours such as pigeon peas, cowpeas, soybeans, the protein content were low (Olaofe et al., 1994, Aletor and Aladetimi,1989, Oshodi and Adeladun 1993). The protein of A africana were higher than of D.microcarpum $11.4 \%$ and $9.1 \%$ of B. eurycoma. The functions of protein which include supply of amino acid, body building and replacement of worn-out tissues may be achieved more on roasting of $A$. africana seed before consumption. The percentage crude fat of A. Africana seed increases on roasting from $16.90+0.01$ to $22.70+0.03 \%$, the crude fat were low when compared with $43.2 \%$ for calabash kernel (Olaofe et al., 2009), and $23.5 \%$ for soybean seed (Paul and Southgate, 1985 ). However these values were higher than $1.93+10.74 \%$ for different cultivar of African yam beans (Adeyeye, 1998). The crude fibre values increases on roasting from $0.13+0.01$ to $2.00+0.03 \%$. These values were low when compared with $2.8 \%$ and $4.28 \%$ for gourd seeds (Ogungbenle, 2006) and soybean 
(Temple et al., 1991) respectively. The ash content reduces on roasting from $0.6+0.03$ to $1.18+0.02 \%$ for fresh A.africana. The seed flour of $A$. africana contained some nutritionally important minerals such as iron $(2.48 \mathrm{mg} / 100 \mathrm{~g})$, calcium $(340 \mathrm{mg} / 100 \mathrm{~g})$, phosphorus $(8.30 \mathrm{mg} / 100 \mathrm{~g})$ and magnesium $(1.60 \mathrm{mg} / 100 \mathrm{~g})$. The seed flour could be useful in supplementing moderate minerals in baby and pre-school children requiring teething and for strong bone formation.

Table 1 : Proximate and mineral composition of fresh and roasted seed flour of $\boldsymbol{A}$. africana

\begin{tabular}{|l|l|l|}
\hline Parameters & Fresh seed flour & Roasted seed flour \\
\hline Moisture & $7.45 \pm 0.02$ & $3.00 \pm 0.05$ \\
\hline Crude protein $(\%)$ & $18.75 \pm 0.03$ & $21.90 \pm 0.04$ \\
\hline Crude fat $(\%)$ & $16.90 \pm 0.01$ & $22.70 \pm 0.03$ \\
\hline Crude fibre $(\%)$ & $0.13 \pm 0.01$ & $2.00 \pm 0.03$ \\
\hline Ash $(\%)$ & $1.18 \pm 0.02$ & $0.60 \pm 0.03$ \\
\hline Carbohydrate & $55.59 \pm 0.05$ & $49.80 \pm 0.04$ \\
\hline Potassium (mg/100g) & $1580 \pm 0.02$ & $1200 \pm 0.01$ \\
\hline Iron & $2.48 \pm 0.01$ & $1.40 \pm 0.01$ \\
\hline Calcium & $340 \pm 0.01$ & $240 \pm 0.01$ \\
\hline Phosphorus & $8.30 \pm 0.02$ & $6.20 \pm 0.02$ \\
\hline Zinc & $2.60 \pm 0.02$ & $1.40 \pm 0.02$ \\
\hline Magnesium. & $1.60 \pm 0.01$ & $0.65 \pm 0.01$ \\
\hline
\end{tabular}

The results of the functional properties (Table 2 ) revealed that the values of water absorption capacity (WAC) increases on roasting from $125.00+2.5 \mathrm{~g} / \mathrm{g}$ to $140.00+5.00 \mathrm{~g} / \mathrm{g}$, the value were comparable with many oil seed defatted flour (100 to $260 \%$ ) (Ige et al., 1984). These values were higher than $138 \%$ (Oshodi and Ekpergin ,1989) and (Olaofe et al., 1994) reported for pigeon pea and gourd seed flour respectively. This indicates that the seed flour of A.africana may be useful in the production of soup and gravies. Also the oil absorption capacity values increases on roasting from $60.00+0.5$ to $88.00+0.7 \mathrm{~g} / \mathrm{g}$ sample. The values were close to the fat absorption capacity of pigeon pea $(89.74 \%$ ) (Oshodi and Ekperigin 1989 and (96\%) of gourd seed flour (Olaofe et al., 1994) but lower than 142.5\% for pumpkin seed flour (Fagbemi and Oshodi,1991). This indicates that the flour can act as flavor retainer and be used to improve mouth feels of food. The emulsion capacity values increases from $30.00 \mathrm{ml} / \mathrm{g}$ to $50.00 \mathrm{ml} / \mathrm{g}$ in both seed flours were observed to be higher than those of soybean $(15.00 \%$ ) wheat flours $(7.00+11.20 \%$ ) (Lin et al., 1974) and calabash seed flour $23.20 \%$ (Olaofe et al., 2009). These suggesting that the seed flour of A.africana could be utilized as substitute for soya and wheat flours in complementary/weaning foods. The foaming capacity increases on roasting from 2.00 to $4.00 \%$ higher than 1.96\% reported for sofin wewe seed flour (Ogunbusola and Adebayo ,2007). Therefore the seed flour of A.africana may not be useful as an aerating agent .

Table 2 : Functional properties of fresh and roaste \pm d seed flour of $A$. africana

\begin{tabular}{|l|l|l|}
\hline Functional properties & Fresh seed flour & Roasted seed flour \\
\hline Water absorption capacity ( \%g/g) & $125.00 \pm 0.5$ & $140.00 \pm 0.7$ \\
\hline Oil absorption capacity (\%g/g) & $60.00 \pm 0.3$ & $88.00 \pm 0.2$ \\
\hline Emulsion capacity (ml/g) & $30.00 \pm 0.4$ & $50.00 \pm 0.3$ \\
\hline Foaming capacity (\%) & $2.00 \pm 0.1$ & $4.00 \pm 0.1$ \\
\hline Bulk density (g/ml) & $0.60 \pm 0.1$ & $0.67 \pm 0.1$ \\
\hline
\end{tabular}

The bulk density of $A$. africana of 0.60 to $0.67 \mathrm{~g} / \mathrm{ml}$ for both fresh and roasted seed flour were higher the values reported for fluted pumpkin $0.42 \mathrm{~g} / \mathrm{ml}$ and for soybean flour $0.47 \mathrm{~g} / \mathrm{ml}$ (Fagbemi et al., 2006 and Chau and Cheung 1998).

\section{Conclusion.}

Roasting process aside a method of preservation has enhances the utilization of the seed flour of A.africana. The high value of water absorption capacity and oil absorption capacity recorded by these underutilized plants indicates that it could be a functional ingredients in food system. This could make the seed flour useful as a protein element as well as flavor retainer and a good substitute for wheat flour and soya flour as an additive / extender in meat and food formulations.

\section{References}

[1]. Adeyeye, E.I. (1998). The relative merits of the presence of hull on the nutritional qualities of the African yam bean flour. Nahurung , 8 (42):84-88.

[2]. Aisegbu , J.E. (1987). Some biochemical; evaluation of fluted pumpkin seed. J Sci. Food Agric. 40:151-158.

[3]. AOAC , (1998). Official Methods of Analysis . $17^{\text {th }}$ Edition, Washington DC USA. Association of Official Analytical Chemist. Pp 9-88

[4]. Deshapande ,S.S. (1992). Food legumes in human Nutrition . a personal perspective . Food Sci Nutri. 32:333-63.

[5]. FAO, (2000). Food Insecurity : When people live with hunger and fear starvation .Rome, Italy :FAO. 
[6]. Fagbemi, T.N., Oshodi, A.A and Ipinmoroti, K.O. (2006). Processing Effect on Some Anti nutritional Factors and In vitro Multi enzyme Protein Digestibility (IVPD) of three Tropical Seeds: Breadnut (Articarpus altilis), Cashew nut (Anacardium occidentalis ) and Fluted pumpkin (Telfairia occidentalis). Parkistan Journal of Nutrition. 4 (4): 250-255.

[7]. Fagbemi ,T.N and Oshodi , A.A (1991). Chemical composition and functional properties of full fat fluted pumpkin seed flour (Telfairia occidentalis ). Nigeria Food Journal 9 :26-32.

[8]. Ige, M.M., Ogunsua, A.O.and Oke,O. L.(1984). Functional properties of the proteins of some Nigerian oil seeds: Conophor seeds and three varieties of melon seeds. Agric and Food Chem.31:822-825.

[9]. Lin , M.J.Y ., Humbert, E.S and Sosulki, F.W (1974). Certain functional properties of sunflower meal products . Jour. Food Sci. 39:368-370.

[10]. Myera , W.(2002). In : Sustainable Food security for all by 2020 . Proceedings of an International Conference. Washington DC: IFPRI p100.

[11]. Ogungbenle, H.N.(2006). Chemical Composition, Functional properties and amino acid composition of some edible seeds. Rivista . Italiana. Delle . Sostanza Marzo. 14; 81-86

[12]. Ogunbusola , E.M and Adebayo, S.F (2007). Functional properties of full fat and defatted lesser known melon seed flour (varColocynthis citrullus). Inter Res Jour. 1:34-35.

[13]. Olaofe, O., Ekuagbere, A.O and Ogunlade ,I (2009). Chemical, amino acid composition and functiona properties of calabash seeds kernel . Bulletin of pure an Appli Sci. 28 (1-2):13-24.

[14]. Olaofe ,O ., Adeyemi, F.O.and Adediran ,U.O.(1994). Amino acid, chemical composition and functional properties of some oil seeds. Jour Agric Food Chem 32 (4) 879-881.

[15]. Oshodi, A.A.and Adeladun, A.O.(1993). Proximate composition, some valuable minerals Functional properties of three varieties of Lima bean flour. Inter Jour. Food Sci and Nutri. 43: 175-181.

[16]. Oshodi ,A.A. and Ekperigin, M.N (1989). Functional properties of pigeon pea (Cajanus cajan) flour. Food Chem 34:187-191.

[17]. Paul, A.A and South gate, D.A.T (1985). Mccane and Widdowsen"s . The composition of food HMSO Royal society of Chemistry, London.

[18]. Steiner, K.G (1996). Causes of soil degradation and approaches to Sustainable soil Management Weikersheim ,Germany: Margrf Verlog p 50.

[19]. Temple, V.J , Odewumi, L and Joseph , K (1991). Soybean and Soybean based diets ,Poceedings of the ${ }^{\text {rd }}$ regional workshop on rural development, Jos pp45-50. 